\title{
Comparative Study of Local Resource Mobilization of Rupandehi's VDCs with National Level
}

Pramshu Nepal, Ph.D.*

\begin{abstract}
In this paper, the researcher defines and analyzes the situation of local resources mobilization patterns by VDCS in national level. The Researcher also studies and compares the situations of Rupandehi districts' VDCs with national level. Similarly, this research tries to identify major income sources of VDCs. This research also tries to identify major internal sources of income of VDCs. Rupandehi district's VDCs have the second highest internal income (Rs. 124.68 millin) in 2013/14 after Kathmandu (Rs. 238.09 million). In comparison to other VDCs of Nepal, the internal income of VDCs of Rupandehi seemed satisfactory.
\end{abstract}

Key Words: Resources, local tax, revenue sharing, grant, internal income, natural resources utilization uax, local bodies.

\section{Introduction}

Resources are the input that the organization can either convert into products or services, or into increasing its own capabilities (Axin, 1978). Resource is an important component to uplift the socio economic condition of people. Availability of resources may be different in different part of the world; however, in any forms or types it is available everywhere at local level. Particular types of resources may available in particular place, such particular resource needs to utilize by combining with other resources in appropriate proportion to produce something otherwise it may be idle. Production of something can enhance the socio economic condition of the people, because idle resource does not possess utility. The identification and utilization of available resources in appropriate proportion is a greater challenge. Fiscal decentralization in Nepal is considered to be low. The share of LBs revenue and expenditure in GDP is very low in comparison to central government's revenue and expenditure. DDCs and VDCs are more dependants in central government's grants. LBs (DDCs, VDCs and municipalities) in Nepal have been given a certain degree of fiscal autonomy to LBs. Out of the total revenue mobilization, the central government collects 96 percent whereas LGs mobilize only four percent. The incomes and expenditures of LGs in comparison to National GDP are very low and rising at a very slow pace. Expenditure of LGs in relation to national GDP ranges between 1.99 percent to 2.40 and the revenue less than four percent during 2006/07 to 2010/11. The sources of income of LBs house tax, land tax, vehicle tax, Haat Bazaar tax, advertisement tax, entertainment tax as tax sources and services charges and fees, income from sales of natural resources and from loan. But, this is not adequate to perform assigned responsibilities. The definitions of the base and rate with a few exceptions are given in the law. In most cases, rate caps are prescribed by the central government. In all these cases, the base is defined in the law. This is the evident of low fiscal decentralization in Nepal. In the context of internal revenue mobilization, Municipalities

*Lecturer, Department of Economics, Butwal Multiple Campus, Butwal 
are relatively better off position than DDCs and VDCs. Municipalities also borrow money from outside while DDCs and VDCs don't.

LBs' total expenditure was Rs. 7505250 thousand in 2002/03 which reached at Rs. 31326940 thousand in 2013/14, more than four folds increase. The income reached at Rs. 35862950 thousand in 2013/14 from Rs. 5914090 thousand in 2002/03, an increase of six folds. Average annual growth rate of LB's total income was 20 percent during this period; however, the OSR has not been increased as expected (LBFC, 2014).

\section{Objective of the Study}

The objective of this article is to categorize the situation of local revenue mobilization patterns of village development committee in national level and to compare the situation of Rupandehi's village development committee with national level for local revenue mobilization.

\section{Methodology}

This article is based on quantitative in nature and the descriptive research design was adopted to meet the objectives. Descriptive research describes and interprets the conditions or a relationship that exits in certain situation. Secondary data were only utilized in this article.

Rupandehi district has forty nine village development committees and six municipalities. It was seven electoral constituencies. In order to represent the district well, seven VDCs were selected which represent one from each constituency. The studied VDCs are Chhipagad, Padisari, Farsatikar, Motipur, Saljhandi, Gonaha and Sipawa.

\section{Village Development Committees's Resources Mobilization Situation in National Level}

In Nepal, LSGA has provided VDCs with revenue mobilization authorities. The local income of VDCs consists of 10 taxes such as house and land tax, land revenue, temporary weekly bazaar, shop tax, vehicle tax, entertainment tax, rent and tenancy tax, advertisement tax, business tax, and commercial video tax. The non tax sources include service fees, charges, penalty, etc.

The total income of VDCs was Rs. 8267850 thousand in 2008/09 which increased to Rs. 9872361 thousand in 2010/11. The highest amount was Rs. 10136673 thousand in 2012/13 while it is Rs. 9512241 thousand in 2013/14. Grant is the major source of income of VDCs. More than 90 percent of the VDCs income comes from the grant while less than 10 percent is mobilized from internal sources. The share was about 95 percent in 2008/09 which decreased to 86 percent in 2013/14 (LBFC,2014). Internal income of VDCs is presented in the table below.

Table 1: Descriptive Statistics of Internal Income of VDCs (in thousands)

\begin{tabular}{|l|c|c|c|c|c|r|}
\hline FY & N & Minimum & Maximum & Sum & Mean & Std. Deviation \\
\hline $2008 / 09$ & 73 & 35 & 106888 & 438500 & 6006.85 & 14981.338 \\
\hline $2009 / 10$ & 75 & 60 & 138088 & 710643 & 9475.24 & 22020.458 \\
\hline $2010 / 11$ & 75 & 271 & 138636 & 904016 & 12053.55 & 23424.779 \\
\hline $2011 / 12$ & 75 & 389 & 179107 & 976493 & 13019.91 & 25752.721 \\
\hline $2012 / 13$ & 75 & 447 & 223884 & 1171322 & 15617.63 & 32296.912 \\
\hline $2013 / 14$ & 75 & 864 & 238090 & 1302241 & 17363.21 & 34784.804 \\
\hline Valid N (listwise) & 73 & & & & & \\
\hline
\end{tabular}

Source: LBFC (2009, 2010, 2013 \& 2014) 
Table 1 provides statistics of internal revenue of VDCs of Nepal. Internal income of VDCs was Rs. 438500 thousand in 2008/09 which reached at Rs. 1302241 thousand in 2013/14. The minimum internal income was Rs. 35 thousand in 2008/09 and increased to Rs. 864 thousand in 2013/14. VDCs of Manang district had lowest average internal income of Rs. 35 thousand in 2008/09 while the lowest internal income was Rs. 864 thousand for VDCs of Rukum in 2013/14. The internal source mobilization of VDCs is meager. Very few VDCs are able to mobilize internal sources of one third of their total income. VDCs of
Okhaldhunga had 0.04 percent of total income in 2008/09, VDCs of 32 districts in 2008/09, 33 districts in 2009/10, 20 district in 2010/11, 6 district in 2011/12, 5 district in 2012/13 (Khotang, Baitadi, Bajura, Rolpa, Rukum), one (Rukum) in 2013/14 had internal income less than one percent of their total income. VDCs of Jajarkot, Khotang, Okhaldhunga, Kalikot, Baitadi, Bajura, Rolpa and Rukum are in the bottom while Kathmandu, Bhaktapur, Lalitpur, Rupandehi, Jhapa, Morang, Kaski, Makawanpur and Dhading are in the top. VDCs of less than eight districts have internal income above 25 percent of the total income.

Table 2: Descriptive Statistics of Share of Internal Income in Total Income, Percent

\begin{tabular}{|l|c|c|c|c|c|}
\hline FY & N & Minimum & Maximum & Mean & Std. Deviation \\
\hline $2008 / 09$ & 73 & .04 & 47.35 & 4.592 & 9.290 \\
\hline $2009 / 10$ & 75 & .04 & 53.74 & 5.883 & 11.215 \\
\hline $2010 / 11$ & 75 & .30 & 50.49 & 7.302 & 11.348 \\
\hline $2011 / 12$ & 75 & .43 & 57.78 & 8.477 & 11.899 \\
\hline $2012 / 13$ & 75 & .47 & 63.55 & 9.405 & 13.220 \\
\hline $2013 / 14$ & 75 & .61 & 65.49 & 10.615 & 13.471 \\
\hline Valid N (listwise) & 73 & & & & \\
\hline
\end{tabular}

Source: LBFC (2009, 2010, 2013 \& 2014)

Table 2 provides statistics of share of internal income in total income of VDCs of Nepal. Minimum share of internal income of VDCs was 0.04 percent in FY 2008/09 which reached at 0.61 percent in FY2013/14. Maximum share of internal income of VDCs was 47.35 percent in FY 2008/09 which reached to 65.49 percent in FY 2013/14. Mean share of internal income of VDCs was 4.592 percent in FY 2008/09 which reached at 10.615 percent in FY2013/14. There is high variation on average share of internal income in total income of VDCs. The maximum share is 58.21 percent while minimum is 0.37 percent during 2009/10$2013 / 14$. The mean share is 8.34 percent. The VDCs of 57 districts have very low internal income. The share of internal income in total income is less than mean share. Similarly, VDCs of ten districts have less than one percent. These districts include Baitadi ( 0.53 percent), Khotang ( 0.53 percent), Rukum (0.61 percent), Rolpa (0.63 percent), Bajura (0.75 percent), Achham (0.87 percent), Bajhang (0.92 percent), Taplejung (0.94 percent), Jajarkot (0.94 percent) and Okhaldhunga (0.98 percent). Top ten districts having high share of internal income in total income of VDCs are Kathmandu (56.60 percent), Bhaktapur (48.24 percent), Lalitpur (41.59 percent), Rupandehi (39.24 percent), Jhapa (37.43 percent), Dhading (36.31 percent), Morang (26.21 percent), Chitawan (21.11 percent), Makawanpur (20.82 percent) and Kaski (20.30 percent) (LBFC, 2014).

\section{Rupandehi's Village Development Committees Resources Mobilization Situation}

Before analyzing the income and expenditure of sample VDCs of Rupandehi, researcher first briefly analyzed the income and expenditure situation of all VDCs of Nepal and all VDCs of Rupandehi district. In 2013/14 the total income and expenditure of all VDCs of Nepal was Rs. 9512.24 million and Rs. 9340.69 million respectively. The total income decreased by 6.16 percent while the total expenditure 
was increased by 13.23 percent during this period. In FY 2013/14, the contribution of total internal income was Rs. 1302.24 million in the same year which covers 13.69 percent of the total income and 13.94 percent of the total expenditure. The contribution of the internal income in total income was 10.27 percent in 2011/12 and 11.56 percent in 2012/13 (LBFC, 2014). Rupandehi district's VDCs have the second highest internal income (Rs. 124.68 millin) in 2013/14 after Kathmandu (Rs. 238.09 million) (LBFC, 2014). ${ }^{1}$ It indicates meager internal income of VDCs. When internal income of individual VDCs analyzed, it is found that the share of internal income of VDCs of
Rukum district is less than one percent and VDCs of 35 districts have less than five percent. VDCs of 20 districts have more than the average 10.62 percent of internal income in their total income (LBFC, 2014). VDCs of Kathmandu have the highest ratio of internal income in total income, ie. 65.49 percent. VDCs of Rupandehi have 44.29 percent (LBFC, 2014). The very few VDCs mobilize internal resources sufficient to incur administrative expenditures. The situation is more pathetic for VDCs of mountain and hill than those of Terai. In total, VDCs are excessively dependent on external sources. The following Table 3 presents the fiscal situation of all the VDCs of Rupandehi.

Table 3: Income and Expenditure of VDCs of Rupandehi District, Rs in thousand

\begin{tabular}{|l|c|c|c|c|c|}
\hline Fiscal Year & $\mathbf{2 0 0 9 / 1 0}$ & $\mathbf{2 0 1 0 / 1 1}$ & $\mathbf{2 0 1 1 / 1 2}$ & $\mathbf{2 0 1 2 / 1 3}$ & $\mathbf{2 0 1 3 / 1 4}$ \\
\hline No. of VDCs & 69 & 69 & 69 & 69 & 69 \\
\hline Grant & 155097 & 142500 & 138761 & 148946 & 156820 \\
\hline Internal Income & 86478 & 74908 & 85274 & 115119 & 124680 \\
\hline Total Income & 241575 & 217408 & 224035 & 264066 & 281500 \\
\hline$\%$ of Int Inco in Tot Inco. & 35.8 & 34.46 & 38.06 & 43.59 & 44.29 \\
\hline Per VDC Income & 3501 & 3151 & 3247 & 3827 & 4079.7 \\
\hline Total Exp & 230053 & 190037 & 194712 & 224390 & 276852 \\
\hline
\end{tabular}

Source: LBFC (2010, 2011, 2012, 2013 \& 2014)

Table 3 shows the total income of all VDCs of Rupandehi district in 2009/10 was Rs. 241575 thousand, which increased to Rs. 281500 thousand in 2013/14. Total income of all VDCs of Rupandehi district was increased by 1.16 times between these periods. Total expenditure of all VDCs of Rupandehi district in 2009/10 was Rs. 230053thousand, which increased to Rs. 276852 thousand in 2013/14. Total expenditure of all VDCs of Rupandehi district was increased by 1.20 times between those periods. In 2009/10 internal source of income was 35.8 percent of the total income and it increased to 44.29 percent in 2013/14. The internal income was Rs. 86478 thousand in 2009/10 and it increased to Rs. 124680 thousand in 2013/14. In comparison to other VDCs of Nepal, the internal income of VDCs of Rupandehi seemed satisfactory.

Table 4: Share of Internal Income in Total Income (Percent)

\begin{tabular}{|l|c|c|c|c|c|c|c|}
\hline Fiscal Year & $\mathbf{2 0 0 9 / 1 0}$ & $\mathbf{2 0 1 0 / 1 1}$ & $\mathbf{2 0 1 1 / 1 2}$ & $\mathbf{2 0 1 2 / 1 3}$ & $\mathbf{2 0 1 3 / 1 4}$ & $\mathbf{2 0 1 4 / 1 5}$ & Average \\
\hline Chhipagad & 3.2 & 4.34 & 6.05 & 8.37 & 10.92 & 8.99 & 6.98 \\
\hline Padisari & 17.54 & 34.61 & 31.91 & 39.45 & 64.35 & 66.96 & 42.47 \\
\hline Farsatikar & 28.93 & 17.56 & 19.37 & 54.84 & 27.04 & 23.75 & 28.58 \\
\hline Motipur & 33.47 & 24.75 & 45.45 & 26.47 & 30.56 & & 32.14 \\
\hline Saljhandi & 17.18 & 12.4 & 13.08 & 15.69 & 20.09 & 22.69 & 16.86 \\
\hline Gonaha & 34.92 & 4.93 & 34.15 & 17.89 & 14.02 & 48.87 & 25.8 \\
\hline Sipawa & 2.46 & 5.3 & 4.12 & 6.25 & 8.37 & 6.89 & 5.57 \\
\hline
\end{tabular}

Sources: Sample VDCs of Rupandehi (2015)

${ }^{1}$ LBFC (2014). Financial analysis of Local Bodies. Local Bodies Fiscal Commission. 
Table 4 presents percentage of internal income in total income for seven sample VDCs of Rupandehi district. The average ratio of internal income to total income during 2009/10 - 2013/14 ranges from 5.57 percent for Sipawa to 42.47 percent for Padisari. Sipawa and Chhipagad have lowest ratio of internal income while Padisari, Motipur and Farsatikar have higher ratio of local income. Sipawa and Chhipagad are located in southern part of district and these VDCs have no access of income from rivers. In 2015, Motipur VDC was taken into Butwal sub metropolitan city. Hence Motipur VDC's data was not available. Major Source of Local Income of Sample VDCs

Table 5: Major Share in Internal Income of Sample VDCS (Percent)

\begin{tabular}{|l|c|c|c|c|c|c|c|}
\hline & Chhipagad & Podisari & Farsatikar & Motipur & Saljhandi & Gonaha & Sipawa \\
\hline House Land Tax & 2.11 & 2.01 & 1.42 & 8.32 & 18.95 & 1.53 & 5.73 \\
\hline Malpot & 57.81 & 7.35 & 10.6 & 11.34 & 8.82 & 19.54 & 54.34 \\
\hline Hat Bazar Tax & 0 & 46.63 & 20.18 & & 13.93 & 17.05 & \\
\hline Commercial Tax & & 11.47 & 0.43 & 0.77 & 0.8 & 12.06 & 12.88 \\
\hline Transportation & & 0.78 & 0.1 & & & & \\
\hline Registration & & 8.1 & & & & & \\
\hline Resource sharing & & & 31.2 & 29.46 & & & \\
\hline Natural Resources & & & 11.97 & 36.52 & & 47.66 & \\
\hline Recommendation & & 17.55 & 13.52 & 0.28 & 16.09 & & \\
\hline Service & & & & 9.36 & 4.41 & & \\
\hline
\end{tabular}

Sources: Sample VDCs of Rupandehi (2015)

Note: The blanks of above table indicate that VDCs were not able to generate income from corresponding headings.

Hat market shop tax: VDCs are entitled to levy Haat market shop tax for shops kept in livestock Haat and regular Haat market, fair, fete, etc. organized within the village development area. Out of the seven sample VDCs, Hat Bazar tax is the major source of income for five VDCs of sample VDCs. Padisari VDC got about 47 percent of its local income from this source during 2009/10-2013/14. Saljhandi, Gonaha and Farsatikar have 13 to 20 percent of local income from Hat Bazar Tax. Chhipagad, Motipur and Sipawa do not have the access of Hat Bazar. Hence these sample VDCs cannot generated income from Hat Bazar tax. Malpot : Malpot is another important source of income for VDCs. The Malpot (Land Revenue or land tax) is levied on the land within the village development area. The proceeds are collected by the VDCs and the legal provision is that 25 percent amount of revenue raised from land revenue or land tax should be handed over to the respective DDC. Among the sample VDCs, Chhipagad has the highest ratio of Malpot in its internal income which is about 58 percent. Malpot income makes more than 54 percent in its total internal income of Sipawa VDC. Malpot makes contribution of seven to twenty percent in internal income for other sample five VDCs.

House and Land tax: House land tax is another source of income of VDCs. Though the contribution of this source in total internal income is not so high, every VDC under consideration has income from house and land tax. It ranges from 1.42 percent for Farsatikar to 18.95 percent for Saljhandi. Saljhandi is located in east and west highway of Nepal and commercial activities are conducting in this VDC. Hence this VDC collected more income from house and lax than other VDCs of sample VDCs. 
Vehicle (transportation) tax: VDCs may levy vehicle registration and annual vehicle tax on the prescribed vehicles within its area and occasional vehicle tax on all kinds of vehicles entering into its area. On the prescribed vehicles entered into Nepal, the VDC of such village development area, through which area such vehicle enters into at first from any foreign country, may levy tax as prescribed and after payment of tax within one village development area, such tax shall be levied again in other places.

Natural Resources Utilization Tax: VDCs may levy tax for commercial exploitation of natural resources and heritage with the village development area. Farsatikar, Motipur and Gonaha have income from natural resources. It is about 48 percent for Gonaha and 37 percent for Motipur. About 12 percent of total internal income of Farsatikar comes from this source. These VDCs have access of income from rivers and crusher factories.
Fees and Charges: VDC may impose and collect service charge on the amount realized by it for somebody else, if it realizes and recovers any other's amount and goods.

\section{Conclusion}

Resource is an important component to uplift the socio economic condition of people. The identification and utilization of available resources in appropriate proportion is a greater challenge. Comparing Municipalities, VDCs is not generating higher internal revenue. Major income sources of VDCs are house and land tax, land revenue, temporary weekly bazaar, shop tax, vehicle tax, entertainment tax, rent and tenancy tax, advertisement tax, business tax, and commercial video tax. The non tax sources include service fees, charges, penalty, etc. Rupandehi district's VDCs have the second highest internal income (Rs. 124.68 millin) in 2013/14 after Kathmandu (Rs. 238.09 million) (LBFC, 2014). While comparing with national average Rupandehi's VDCs were generated more income from internal income.

\section{References:}

Axin, G. H. (1978). New strategies for rural development, Collection of Paper by George Axin, Michigan State University, and Tribhuvan University, Kathmandu, Nepal.

District Development Committee, [DDC Rupandehi]. (2015). District Development Programme, FY 2073/74 BS. Rupandehi: District Development Committee.

LBFC, (2013). Financial Analysis of Local Bodies, Kathmandu, Local Bodies Fiscal Commission Secretariat. Local Bodies Fiscal Commission [LBFC]. (2011). Minimum conditions and performance measures of local bodiesin Nepal: An overview, assessment years 2007/08-2010/11. Pulchok, Lalitpur: Local Bodies Fiscal Commission Secretariat.

Local Bodies Fiscal Commission [LBFC]. (2011). Fiscal analysis of local bodies. Pulchok, Lalitpur: Local Bodies Fiscal Commission Secretariat.

Local Bodies Fiscal Commission [LBFC]. (2012). Fiscal analysis of local bodies. Pulchok, Lalitpur: Local Bodies Fiscal Commission Secretariat.

Local Bodies Fiscal Commission [LBFC]. (2013). Financial analysis of local bodies. Kathmandu: Local Bodies Fiscal Commission Secretariat.

Local Bodies Fiscal Commission [LBFC]. (2014). Financial analysis of local bodies. Kathmandu: Local Bodies Fiscal Commission Secretariat.

Local Bodies Fiscal Commission) (LBFC). (2016). Fiscal Analysis of Local Bodies. Lalitpur: LBFC. 